\title{
O EGITO COMO LIMIAR E O HERÓI EM XEQUE EM HELENA DE EURÍPEDES
}

Lorena Lopes da Costa ${ }^{1}$

\begin{abstract}
Resumo
O presente artigo tem como objeto a peça Helena de Eurípides, datada de 412 a. C., e busca apreender de que forma o Egito, terra onde se desenvolve a versão do mito narrada pelo poeta, atualiza a Esquéria, ilha em que Odisseu redefine seu retorno ao narrar suas aventuras na Odisseia. Para estabelecer as afinidades com a terra dos feácios, o poeta trágico apropria-se da visão grega do Egito, em que a admiração e o mistério são os aspectos principais, e incorpora elementos odisseicos ao enredo, o que lhe permite recriar uma história em que o herói e a guerra são postos em xeque.
\end{abstract}

\section{Palavras-chave}

Egito; Esquéria; Herói; Guerra; Limiar.

\begin{abstract}
This paper tries to catch how Egypt, land where Euripides develops the version of the myth narrated in Helen (412 BC), updates Scheria, island where Odysseus redifines his return narrating his adventures in the Odyssey. In order to establish the affinities with the Phaeacians' island, the tragic poet appropriates the Greek view of Egypt, in which wonder and mystery are the main aspects, and incorporates odyssean elements in the plot, what enables him to recreate a story in which the hero and the war are into question.
\end{abstract}

\section{Keywords}

Egypt; Scheria; Hero; War; Threshold.

\footnotetext{
${ }^{1}$ Professora Doutora, Universidade Federal do Oeste do Pará - Santarém, Brasil. email: lorenalopes85@gmail.com
} 
Introdução: Helena de 412 a. C.

Na história que nos conta Eurípides em 412 a. C., como a Helena real tivesse sido enviada ao Egito por vingança de Hera, o que seguira para Troia em seu lugar não era nada mais que uma imagem. É por essa

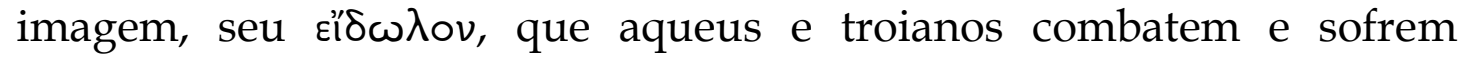
inúmeros males durante os dez anos de guerra, até que o incêndio e a destruição de Ílion ponham fim ao conflito e deem início aos retornos.

Essa Helena, por mais que isolada no Egito ao longo do conflito entre aqueus e troianos, tem consciência dos males da guerra e imputa a si mesma a culpa desses males: "muitas vidas, por minha causa, junto do Escamandro, de suas correntes pereceram" (Helena, v. 52-3). Na peça, ela ouve de Teucro o quanto é odiada na Hélade. Segundo o irmão de Ájax, que chega ao Egito depois de ser expulso da pátria, Helena é a mais

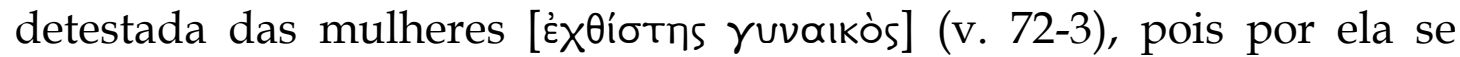

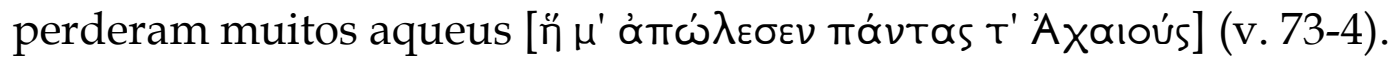

Eurípides não foi, certamente, o primeiro dos gregos a odiar e a amar Helena, explorando a ambiguidade da personagem². Filósofos, sofistas, poetas debatem sobre a personagem. Na tragédia, em termos gerais, o

\footnotetext{
${ }^{2}$ Em que pese a controvérsia sobre a influência entre os heróis épicos e os heróis de culto (Van Wees, 2006), Helena é tanto matéria de culto na Lecedemônia, quanto pertencente à linhagem dos heróis em Hesíodo. Em Trabalhos e Dias (v. 154-81), Helena, ao lado de Édipo e Cadmo, é um dos poucos integrantes individualizados da linhagem dos heróis. Em Homero, veem-se duas posturas em relação à Tindárida, quais sejam a de ódio e a de admiração, misturarem-se. Na Ilíada, não há dúvida de que os dois sentimentos estão presentes. Helena escuta dos anciãos nas portas Céias: "Não é ignomínia que Troianos e Aqueus de belas cnêmides sofram/ durante tanto tempo dores por causa de uma mulher destas!" (Iliada, III, 156, tradução de Frederico Lourenço). Para Príamo, não Helena, mas sim os deuses seriam os causadores da guerra. Mas a Helena iliádica avalia a si mesma e afirma que teria preferido morrer a ter causado a guerra (Il., III, 173-6; III, 241-2; VI, 343-58; XXIV, 763-4). Nas Cíprias, o poeta admite que Helena havia sido o instrumento de um plano divino. No Ciclo Épico, há ainda outras referências a Helena. Da Pequena Ilíada, sabe-se que, em decorrência da morte de Páris por uma das flechas de Filoctetes, Helena é desposada por Deífobo (Pequena Ilíada, 216). E do Saque de Ílion, tem-se que Deífobo é assassinado por Menelau, o qual, finalmente, captura a esposa (Saque de Ílion, 259-60). Na Odisseia, a ambiguidade em torno da personagem de Helena e de sua relação com a guerra é ainda mais forte. Eumeu, o fiel porqueiro de Odisseu, deseja o fim da raça de Helena por ter ela causado a morte de muitos homens: "quem me dera que morresse Helena e toda sua laia" (Odisseia, XIV, 68-9). Odisseu tem também palavras duras para lamentar a destruição causada por ela e sua irmã, Clitemnestra: "Ai, Zeus de ampla vista detestou na verdade/ a descendência de Atreu, por causa das intrigas femininas" (Od., XI, 436-7). Ela mesma e Menelau, de volta à casa, contam a Telêmaco duas versões distintas sobre sua participação na guerra. Górgias, Isócrates, Platão (não apenas em Fedro e na República) discutem seu comportamento e sua culpa. Na poesia, Safo (Fr. 166, 116) e Alceu (Fr. 42, 283), antes de Eurípides, realçam na paixão a força motivadora do comportamento de Helena e nessa força enxergam a intervenção divina de Eros e Afrodite. Teócrito, depois deles, visita a Tindárida com seu Epitálamo de Helena e Licofron, em sua Alexandra, retoma a ideia de um fantasma de Helena, apresentando outra variação para a história.
} 
ódio a Helena é, muitas vezes, substituído. Ésquilo, por exemplo, apesar das injúrias pontuais, nos epítetos que lhe dá (Agamêmnon, v. 687; v.

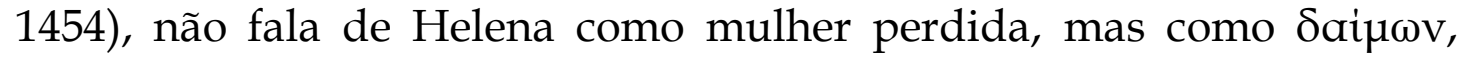
força divina (v. 445 e v. 799). Em Eurípides, a condenação de Helena é insistente e declarada em Andrômaca (v. 426), Hécuba (v. 424), Troianas (v. 415), Orestes (v. 408), Ifigênia em Áulis (v. 406). Em Helena de 412 a. C., porém, o poeta parece deixar de lado o julgamento recorrente para levar ao extremo a ambiguidade da personagem. E ele o faz escolhendo narrar a versão do mito em que Helena vai ao Egito - do que o Ciclo Épico, e tanto a Ilíada quanto a Odisseia dão alguma mostra, embora seja mais evidente em Heródoto (II, 113-20), onde há menção ao engano dos aqueus, ainda que sem qualquer menção à duplicidade de Helena.

O historiador, sem dúvida, está em busca de uma explicação racional

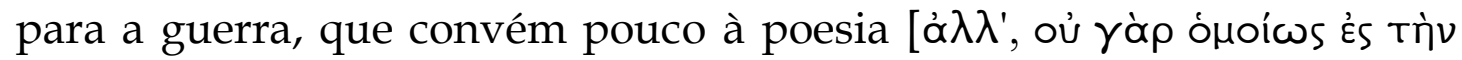

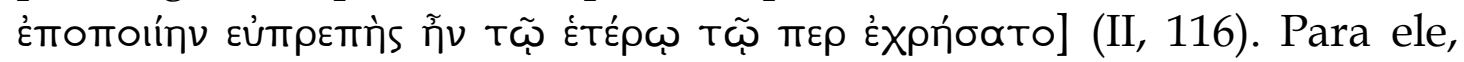
preocupado com o encadeamento histórico dos fatos, o engano tem outra natureza. Heródoto relata que Páris, tendo raptado Helena e alguns tesouros, segue de volta à pátria, mas os ventos o levam à costa egípcia, onde é denunciado às forças locais. Segundo o historiador, é Proteu, rei do Egito, quem toma a frente da questão e impede que Helena prossiga com seu raptor. Proteu decide guardar a mulher e os tesouros até o dia em que Menelau fosse buscá-los. Quando isso finalmente acontece, ele dá ao filho de Príamo três dias para deixar suas terras. ${ }^{3}$ Tão bem recebido no reino de Proteu quanto sua esposa havia sido tratada durante os dez anos de guerra, Menelau retoma suas posses e prepara-se para retornar à pátria ao lado da mulher, sendo, no entanto, impedido de partir pelo mau tempo. Em busca de aplacar a intempérie, decide-se por sacrificar duas crianças da terra. É então que desperta o ódio das gentes egípcias, por quem passa, de fato, por esse motivo, a ser perseguido.

Heródoto opta por incluir o Egito na versão que adota, mas não fala de fantasma algum. Segundo um escoliasta de Licofron, Hesíodo teria sido o primeiro a falar do fantasma de Helena (v. 822, escólio de Alexandra de Licofron), mas é Platão quem deixa registrada a alusão mais antiga à duplicidade de Helena, ao citar três versos de Estesícoro, poeta do século VI a. C., de quem um fragmento descoberto no século $\mathrm{XX}$,

\footnotetext{
${ }^{3}$ Antes, os helenos enviam a Troia uma embaixada para requisitar Helena e os tesouros levados por Páris, recebendo a recusa dos destinatários, uma vez que nem Helena nem os tesouros encontram-se lá. Sentindo-se zombados, os aqueus decidem-se pela guerra e só acreditam na sinceridade da resposta troiana quando nem a derrota nem a destruição de Ílion são o suficiente para trazer de volta a esposa a Menelau. Só então ele parte com sua frota para o Egito.
} 
preservado pelo Papiro de Oxirrinco 2506, comprova a citação do filósofo (Woodbury, 1967; Beecroft, 2006):

\author{
Foi mentira quanto eu disse. \\ Nunca subiste nas naves \\ de belas proas recurvas, \\ nem no castelo de Troia \\ jamais pisaste algum dia. \\ (Fedro, 243 a7 - b1, tradução de Carlos Alberto Nunes)
}

Nos versos atribuídos por Platão a Estesícoro, a Helena de Troia não teria existido; ao menos não teria existido uma Helena de carne e osso em Troia. Ela não teria, enfim, ido a Troia e Troia, por isso, não a teria

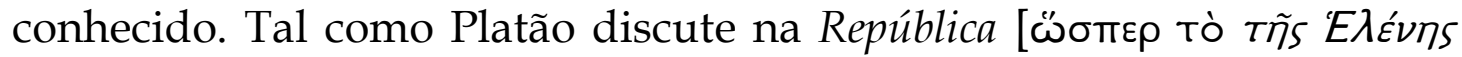

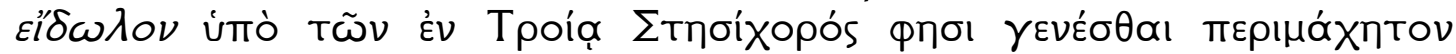

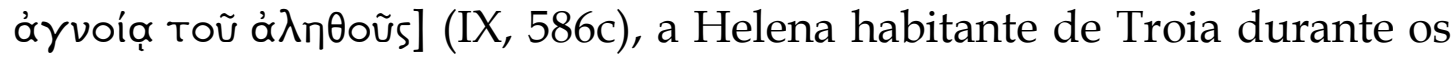
anos de guerra não teria sido mais do que um $\varepsilon^{\prime} \delta \omega \lambda \circ v$, uma imagem, um simulacro, um duplo, um fantasma, um não-ser, que, a despeito de sua existência vazia, gera prazer e ódio plenos, faz com que os homens façam a guerra, e que a guerra, o prazer e o ódio existam. Helena, em Estesícoro e em Platão, dessa forma, não teria passado de uma imagem falsa por quem os gregos se batem contra os troianos por ignorarem a verdade.

Tanto a citação de Platão quanto o fragmento de Estesícoro guardam em comum com Eurípides a diferença com relação ao mito do rapto de Helena tal como narrado por Homero. Em Platão, ainda, a diferença ganha reforço com a história de vida de Estesícoro. A criação da Palinódia, segundo o filósofo, havia servido ao poeta como um rito de purificação, pois, tendo errado na mitologia (na criação dos mitos), narrando a história de Helena de forma inadequada, Estesícoro havia sido punido com a perda da visão. O poeta resolve, contudo, retratar-se com os deuses para recobrar a capacidade de ver e corrige o mito, narrando-o novamente da forma correta (Fedro, 243).

A tradição é rica em histórias sobre Helena e o século $\mathrm{V}$ as faz proliferar. A genealogia do mito evidencia a popularidade da história e da personagem de Helena, sobretudo no século V e IV, e alimenta a dúvida acerca das motivações da escolha de Eurípides pela versão menos popular da história, distinta da narrada por Homero, e cujo tom é distinto daquele que orienta as referências a Helena em suas outras peças. É verdade que já em Electra, peça que é provavelmente anterior à

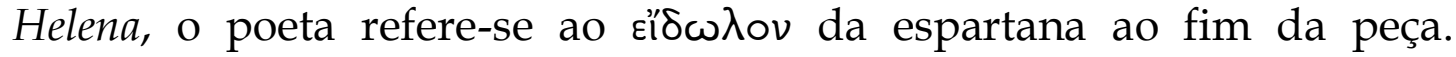
Castor, seu irmão, anuncia, em conformidade com o que é narrado em 
412 a. C., que ela havia passado os anos de guerra no Egito, no palácio de Proteu, sem nunca ter ido a Troia.

\author{
Helena honrará. Ela, depois de deixar o Egito, \\ chega da casa de Proteu, não vem da Frígia - é que \\ Zeus queria germinar discórdia e morte pros viventes,

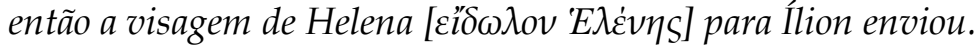 \\ (Electra, v. 1288-1291, tradução de Tereza Virgínia Barbosa)
}

Mesmo que breve, a referência, provavelmente de 413 a. C., já sintetiza a ideia que Eurípides desenvolverá em Helena. Os Dióscuros de Electra aludem, enfim, ao argumento da peça de 412: Zeus envia a Ílion, não

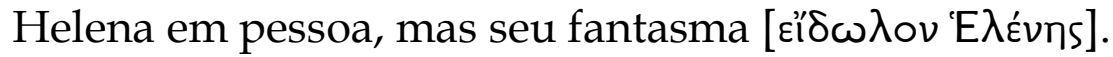

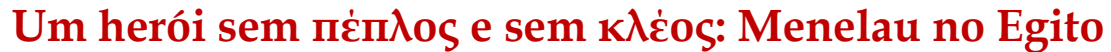

Ao escolher tal versão do mito, a de que Helena de Troia não passara de uma imagem, Eurípides faz com que o herói da peça, Menelau, transforme-se num herói cuja causa não é mais do que uma causa também aparente. Ele, como Odisseu, que só depois de passar pela Esquéria pode seguir para Ítaca, para retornar de fato da guerra, tem que passar pelo Egito antes de voltar a sua terra. Lá, no reino de Proteu, Menelau reconhecerá Helena e reconhecerá que lutara dez anos por um fantasma, por uma nuvem. Só então, depois desse duplo reconhecimento, ele poderá passar de um mundo a outro. Como Odisseu, depois da misteriosa travessia no mar, Menelau chega ao Egito sem qualquer marca que lhe permita ser reconhecido. Ao chegar, Menelau tem consciência de quão frágil é sua condição, de quão irreconhecível é aos habitantes da terra estrangeira:

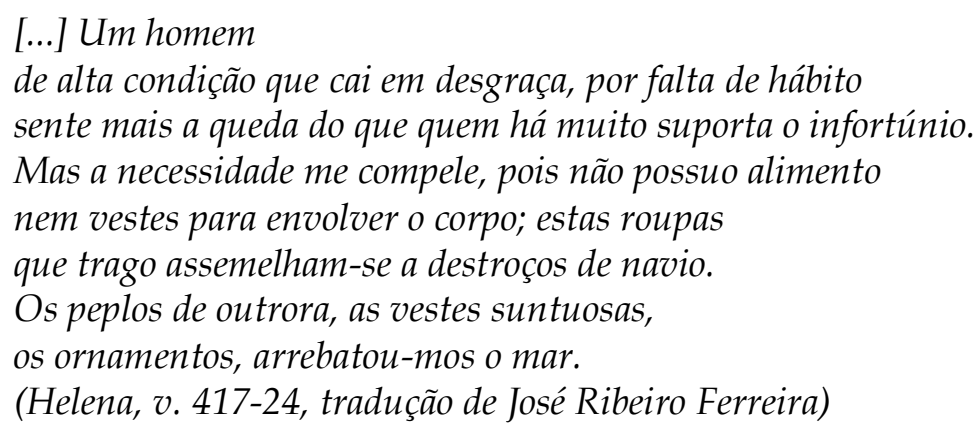

Menelau chega ao Egito maltrapilho, espoliado de toda marca identitária e de toda glória que a guerra havia lhe conferido. À serva, que é a primeira pessoa vista por ele em terra egípcia, diz: "Ai de mim! Onde está meu glorioso exército?" (Helena, v. 453). Menelau vê contrastarem-se seu passado glorioso de guerreiro e sua carência total. 
Não é que ele não saiba agir em relação ao naufrágio, ao sofrimento do corpo, à fome, pois o herói sabe lidar com as condições mais adversas; ele comprova-se herói na medida mesmo em que seu corpo e seus limites são desafiados. O que para Menelau mostra-se difícil, portanto, são as exigências do retorno, uma espécie de etapa na constituição do herói que, não tendo morrido na guerra, será ou não será reconhecido como herói em vida. ${ }^{4}$ Menelau chega à terra estrangeira sabendo que não é o mesmo que era na guerra: permanece o orgulho "dos prósperos êxitos dos tempos de outrora" (Helena, v. 457), ${ }^{5}$ mas já não há navio, nem pompa, nem seu valor é reconhecível aos olhos do outro. Ao naufragar, ao perder tudo, ele se enxerga na pele de um ilustre desconhecido, mesmo tendo conquistado fama com a guerra. Enfim, descaracterizado, é que ele vai poder entender que tipo de guerreiro foi em Troia. Menelau, na chegada ao Egito, revela-se orgulhoso de seus feitos na guerra, mas, a despeito disso, consciente dos sofrimentos que causara:

Considero grande feito - e digo-o sem orgulho fazer embarcar para Troia tão grande exército, sem recorrer à força de tirano, mas à dos chefes; e a juventude da Hélade me seguia de livre vontade.

E podem-me contar os que já não existem e os que, felizes, escaparam aos perigos do mar, para levar às casas os nomes dos mortos.

Mas eu, pelas ondas profundas do mar glauco, ando errante, infortunado, desde o tempo em que em Ílion destruí as torres; e, desejoso de regressar à pátria

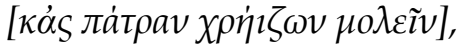
não se dignam os deuses conceder-me essa graça. As zonas costeiras, desertas e inospitaleiras, da Líbia, todas elas já abordei; e, quando me aproximo da terra pátria, de novo o vento me afasta e nunca se mostra favorável em soprar nas velas de modo a levar-me ao país

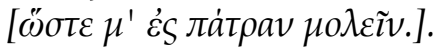

E agora, infeliz náufrago, perdidos os companheiros, fui atirado para esta terra; o barco contra os rochedos estilhaçou-se em grande número de destroços.

(Helena, v. 393-410)

\footnotetext{
${ }^{4}$ Não é a tragédia que decide quem retorna e quem não retorna para a pátria depois da Guerra de Troia. Essas escolhas são escolhas do mito que antecedem a tragédia. O Ciclo Épico, a Ilíada, a Odisseia, já sabem dos heróis que morrem na guerra, dos heróis que morrem no retorno e dos heróis que retornam com vida. Mas o teatro dá seu próprio contorno à relação entre a forma do retorno (ou do impedimento do retorno) e a guerra.

${ }^{5} \mathrm{Em}$ geral, argumenta-se sobre o valor cômico da cena, em que a serva pergunta ao náufrago por que ele chora, do que ele lamenta, obtendo dele a resposta: "Dos prósperos êxitos dos tempos de outrora" (Helena, 457). O que parece ser divertido opõe o orgulho de Menelau à situação adversa.
} 
Antes de entender que a guerra havia sido feita por uma nuvem, ele insiste em reafirmar tal fama, reconhecendo os males do combate, mas não a inconsistência da causa, tal como diz a Helena: "Convence-me o volume de males sofridos em Troia,/ mas tu não" (Helena, v. 593). Menelau é, por isso, motivo da ironia cruel do poeta, bem como o são todos aqueles que guerrearam a seu lado: eles lutaram por nada. Somente no Egito, depois de feita a guerra, Menelau vai descobrir seu fracasso, ao perceber que sua glória, ao menos ali, no Egito, é inócua: "Famoso é o incêndio de Troia, e fui eu quem o ateou,/ eu, Menelau, de modo algum desconhecido em toda a terra" (Helena, v. 403-4).

\section{Egito de Eurípides como travessia entre a guerra e a pátria}

Desde os primeiros versos da peça, o público é informado de que Helena está, enquanto a guerra é feita, no Egito, lugar por excelência onde real e irreal se misturam e que, nesse sentido, evoca claramente a Odisseia e a terra de Alcínoo, onde o herói precisa igualmente reconhecer-se e se fazer reconhecido para poder, enfim, retornar à pátria, ao fim da guerra. Esse vai e vem entre dois mundos aponta para o vai-e-vem entre a ilusão e a verdade, entre o nome e a coisa, a imagem e o ser: o desafio da peça. De um lado, há o mundo real, representado de forma realista tanto pela guerra de muitos sofrimentos quanto pela pátria; de outro, há o mundo maravilhoso do Egito, apresentado de forma pitoresca e fabulosa, em que a magia é possível, os perigos são muitos e as verdades são abaladas. O poeta se pergunta, por meio da figura mesma de Helena, como reconhecer o que é verdadeiro e o que é falso, como discernir entre um e outro? Ela e Menelau precisarão responder a essas questões, ainda que minimamente, para atravessar o mundo pitoresco e fabuloso e cumprirem o trajeto que liga, finalmente, a guerra à pátria.

Na peça, o Egito corresponde à beleza e à ambiguidade de Helena, tal como revela a descrição que Teucro, antes de Menelau, faz ao chegar lá (Helena, v. 68-70). O Egito é exatamente o contrário de Troia: lá se pode guardar intacta a beleza e a fidelidade de Helena, embora, ao lado da imagem mítica e benevolente de Proteu e da virgem Teónoe, que resguardam a hóspede, esteja a do violento Teoclímeno. No Egito euripideano, vê-se, ao lado da riqueza, da beleza e da fidelidade, a ameaça constante da violência e da infidelidade. Esse Egito ambíguo de Eurípides é, por certo, um Egito helenizado. As personagens egípcias são gregas de nome, falam grego e seus cultos são gregos também. Teónoe adora os deuses do Olimpo e não conhece outros senão eles. 
Não obstante helenizado na peça, o Egito representa para o público que lhe assiste a mistura numa mesma imagem da alteridade admirável da civilização antiga, sobre a qual Heródoto nos informa, e da zombaria e do deboche, a despeito de sua história. Teoclímeno, o rei cruel, filho do generoso Proteu, oferece com sua crueldade uma confirmação evidente do senso comum sobre o Egito, pois sua figura não é uma figura marginal na visão grega sobre os reis egípcios. Contam Heródoto e Diodoro que Proteu, o rei hospitaleiro, é a exceção entre os reis egípcios, via de regra xenófobos e violentos. Conta-se que os soberanos egípcios anteriores a Psammético haviam impossibilitado o acesso dos estrangeiros a sua terra, assassinando ou escravizando aqueles que, apesar da proibição, conseguiam chegar a seu reino. Tal lenda, para Diodoro, teria gerado a fama da xenofobia egípcia (Diodoro, I, 67).

A crueldade do rei preserva na peça algo da maneira egípcia aos olhos do público. A regra é mesmo que a hospitalidade ceda à violência arbitrária. Os senhores daquele palácio, informa a serva, a que primeiro avista o náufrago Menelau, não têm relação alguma com os gregos e qualquer que seja o grego que se aproxime, ele morrerá (Helena, v. 43940), pois Teoclímeno, o filho de Proteu, é seu pior inimigo ['E

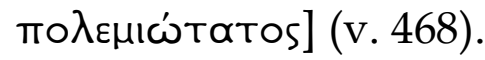

Pois não chegaste em ocasião oportuna. Se o meu senhor te encontra, a morte será a hospitalidade que te dará.

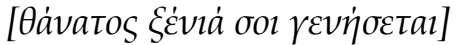

Eu sou benevolente para os helenos e só amargas palavras te dirijo, por receio ao meu patrão.

(Helena, v. 479-82)

O Egito, segundo o poeta, só tem uma regra para receber seus hóspedes, ao menos os gregos: matá-los. A morte é a hospitalidade que se sabe dar por lá. No entanto, embora seja essa a orientação oficial, nem todos os anfitriões seguem-na à risca. $\mathrm{O}$ Egito de Eurípides, nesse sentido, deve e não deve ao Egito de Heródoto, com quem os gregos aprenderam sobre o Egito de outras épocas. A serva, a primeira a comunicar o risco ao estrangeiro, é a primeira a protegê-lo. Como acontece com Odisseu ao chegar à terra feácia, Menelau, ao deparar-se com a serva e depois com Helena, é um náufrago sem suas vestes de rei, sem proteção, sem saber em que terra pisa, a deparar-se, antes de encontrar os homens da terra, com as mulheres. Com a serva e com Helena, Menelau descobrirá que tipo de anfitrião encontrará: "Foge o mais depressa que puderes e afasta-te desta terra/ Receberás a morte do homem que vive neste palácio" (Helena, v. 780-1), diz Helena a seu esposo. Odisseu, embora de forma menos explícita, corre alguns riscos sendo 
estrangeiro na Esquéria. Com efeito, a não associação dos feácios com outros povos, sua insularidade (Villate, 1991), ${ }^{6}$ sua não-hospitalidade são sugeridos, por exemplo, quando Nausícaa, orientando Odisseu a seguir sozinho em direção ao palácio de Alcínoo, explica o comportamento de seu povo, que poderia maldizê-la, vendo-a

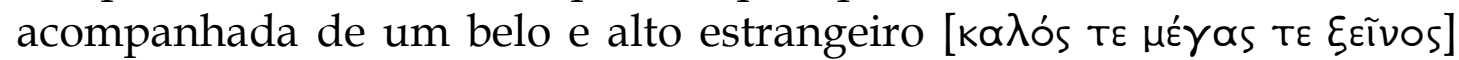
(Odisseia, VI, v. 276-7), pois:

\section{Esta população não é muito amiga de estrangeiros,} nem é seu costume dar as boas-vindas a quem chega de longe. É um povo que confia apenas nas suas rápidas naus velozes, nas quais atravessa o abismo do mar, por graça do Sacudidor da Terra.

Pois suas naus são rápidas como uma flecha ou um pensamento. (Odisseia, VII, v. 32-36, tradução de Frederico Lourenço)

Desses feácios, povo sem vizinhos, sem associação com outros povos, resta porém, não uma inimizade irrestrita aos estrangeiros, que ameaçaria fatalmente o retorno de Odisseu à pátria, como a fala de Nausícaa parece sugerir, mas uma incerteza com relação ao tema, que poderá se desenvolver positivamente para o estrangeiro, de acordo com seu comportamento. Gilbert Rose (1969) argumenta que, ao contrário da opinião comum acerca da boa hospitalidade dos feácios, eles o recebem com suspeita e desconfiança, movendo-se gradualmente em direção à generosa acolhida, de modo que Odisseu ganha a lealdade de um povo que está longe de estar pronto para oferecer ao estrangeiro um paraíso em que hostilidade e receio inexistam. ${ }^{7}$

Em Helena, igualmente sem ser amigo de estrangeiros, Teoclímeno, diante da chegada de um náufrago (Menelau disfarçado) portador de uma notícia favorável (a morte de Menelau no mar), só age como pedem as regras da boa hospitalidade devido à encenação de luto de Helena e à ideia de que finalmente poderia se casar com ela (tudo saindo conforme os planos arquitetados pela própria Helena). A inimizade declarada aos gregos, assim, cede à boa nova. O estrangeiro é

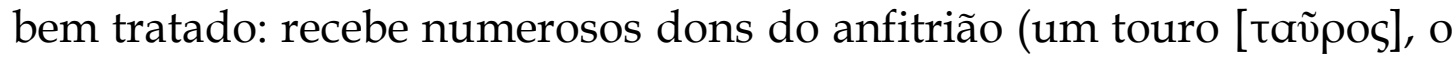

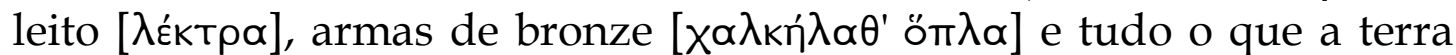

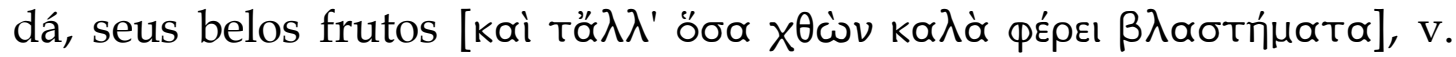
1258-1265), conta sua história, pode banhar-se e vestir uma túnica nova. No limite, poderá retornar à pátria e, contrariando as expectativas de

\footnotetext{
6 A noção de insularidade e o termo para designá-la não existem em Homero, mas apenas ilha, nêsos.

${ }^{7}$ A opinião de Gilbert Rose é contrária a uma tradição que identifica, nos feácios, um povo hospitaleiro e, em sua terra, uma espécie de paraíso. Nessa tradição, destacam-se nomes como: Charles Segall, C.H. Whitman, G. Lord e Combellack.
} 
Teoclímeno, levará o que é seu (além dos dons recebidos, sua mulher, Helena), por meio do que é do senhor (um barco e remadores). Teoclímeno, como Alcínoo, a princípio assegura a seu hóspede o retorno:

\author{
Seja. É do meu interesse manter a minha mulher piedosa. \\ Entra no palácio e escolhe a oferenda para o morto \\ [lacuna] \\ e não te enviarei com as mãos vazias desta terra, \\ por fazeres uma coisa que the agrada. E de mim, por novas \\ felizes me trazeres, obterás, em vez dos farrapos que te cingem, \\ vestuário e alimentos suficientes que à pátria te permitam \\ regressar, porque agora te vejo em estado digno de lástima. \\ (Helena, v. 1278-84)
}

A descrição dos dons sinaliza não apenas a boa e inédita hospitalidade de Teoclímeno - um faraó egípcio dando hospitalidade a um grego como a fartura e a riqueza de sua terra. Por isso, numa cena em que diversos elementos evocam a chegada de Odisseu à Esquéria, é improvável pensar que a menção à boa terra do Egito não tenha evocado o farto canteiro de Alcínoo, onde "a pêra amadurece sobre outra pêra; a maçã sobre outra maçã;; cacho de uvas sobre outro cacho; figo sobre figo" (Odisseia, VII, v. 114-21).

A ilha dos feácios, como propõe Steve Reece (1993), tanto um limiar geográfico quanto psicológico entre dois mundos, é lugar em que o nóstos de Odisseu se define na Odisseia não por ser seu início, nem tampouco seu fim, mas por torná-lo possível. Ela é tanto o limite entre o mundo real e o mundo fabuloso, como sugere Vidal-Naquet (1970), quanto a transição ou o limiar entre duas áreas de experiência bastante diferentes: a guerra de Troia e o reino de Ítaca. É lá que Odisseu compreende que, para retornar de fato à pátria, ele precisa reconhecer seu passado, reconhecendo-se a si mesmo. Para Charles Segal (1994), aliás, o caminho de volta de Odisseu deve ser pensado, não exatamente no sentido do que propõe Vidal-Naquet (1970), como caminho de resgate de sua humanidade, mas, mais especificamente, caminho de volta à mortalidade. É para dar-se conta de ser mortal que Odisseu precisa ouvir e narrar suas experiências de um passado inumano, porque imortal (quer dizer, já imortalizado pelo canto de Demódoco, narrativa anterior àquela que ele próprio profere): "a avaliação de Odisseu de suas experiências no mundo irreal ocorre exatamente na sombra de seu retorno à realidade: apenas um raiar do sol, ansiosamente esperado, separa esses 
dois mundos" (Segal, 1994: 19), 8 o real, mundo para o qual tenta retornar, do irreal, mundo de onde partirá.

De todos os elementos que aproximam a Esquéria do Egito, o mais forte é, justamente, o reconhecimento enquanto prova a ser vencida para o cumprimento do retorno. Tanto Helena quanto Menelau experimentam essa prova no Egito, para só então estarem aptos a retornar à pátria, transformando ainda mais o Egito numa terra limítrofe entre a experiência da guerra e o retorno, entre dois mundos. No Egito, Menelau e Helena hão de reconhecer-se um ao outro, mas, sobretudo, como ocorre com Odisseu, cada um dos dois há de reconhecer-se a si mesmo. Cada um deles reconhecerá seu passado: Menelau há de reconhecer-se como o guerreiro de uma guerra vazia de motivo e Helena como a culpada de uma guerra cujas imagens lhe chegam avassaladoras por meio dos estrangeiros no Egito (Menelau, seu servo e Teucro). Pela primeira vez, em dez anos de guerra e sete de errância, Menelau narra os sofrimentos da guerra e se defronta com as questões que a história real de Helena colocam diante de sua experiência mesma na guerra.

Na Esquéria, Odisseu experimenta a miséria, de bens e de fama, para retomá-los, tanto os bens quanto a fama, à medida que conta sua história. No Egito, Menelau experimenta um processo parecido, pois, se ao chegar é um desconhecido, desapossado de seu exército e de sua glória troica, ao partir, ele retoma o exército de companheiros com o qual tomara Ílion, retoma o reconhecimento de sua excelência heroica, mas, sobretudo, a legitimidade da guerra, pois captura Helena, a verdadeira Helena. É exatamente a fim de atualizar a glória troica que perguntam tanto Helena quanto Menelau no combate final: "Onde a

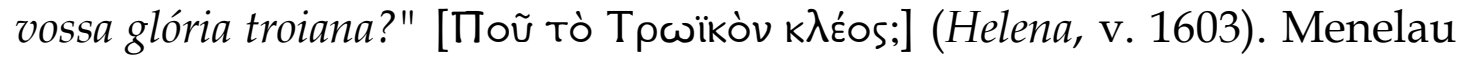
é um herói, portanto, que, como Odisseu, poderá retornar à pátria após atravessar o limiar entre dois mundos, mas, diferentemente do filho de Laerte ${ }^{9}$, Menelau só poderá transitar de um mundo ao outro se fizer a guerra novamente.

\footnotetext{
8 Texto original: and Odysseus' review of the totality of his experiences in the unreal world occurs in the very shadow of his return to reality: only one eagerly awaited dawn separates the two worlds.

${ }^{9}$ É certo que para voltar à pátria, Odisseu precisará, de alguma maneira, conquistar de seus anfitriões feácios o consentimento e que esse consentimento será o resultado de alguns enfrentamentos indiretos, já que o Laertíade é alvo da desconfiança do povo de Alcínoo, sendo, no limite, insultado por Euríalo (Od., VIII, 140-164). Mas não ocorre na Esquéria nenhum enfrentamento direto que se aproxime do que se dá no Egito na peça de Eurípides. $\mathrm{Ou}$, nesse caso, deveríamos considerar que também Odisseu faz a guerra, ao matar os pretendentes em Ítaca, para, de fato, retornar à pátria?
} 
A nova guerra no Egito ou a guerra covarde de Menelau: atualização da glória ou desconstrução do herói?

Se o Coro da peça de Eurípides é claro em sua mensagem de que a guerra é inútil e Helena é capaz de imaginar os horrores da guerra (v. 38-9, 109, 196-210, 362-74, 383-5), ela, nem por isso, hesita em conclamar o uso da violência para atingir seu objetivo. É Helena quem maquina o plano da batalha no mar, além de ser ela quem prepara Menelau para

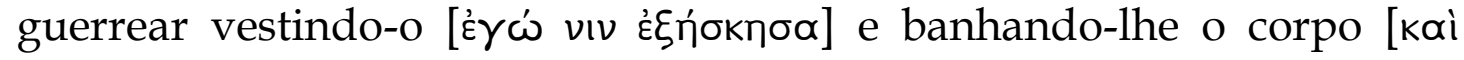

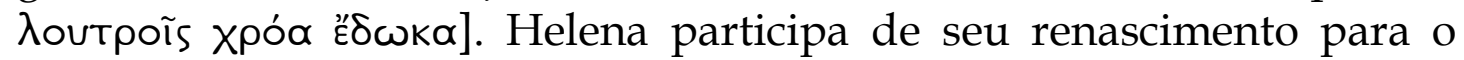
embate contra os egípcios, o qual vai atualizar a Guerra de Troia, dando para a nova guerra um motivo real.

Tendo o plano de Helena dado certo (a fuga do palácio de Teoclímeno, sob alegação de que apenas prestariam homenagens a Menelau morto e retornariam), após imolar o touro já em alto-mar, o filho de Atreu conclama seus companheiros à batalha final: "Que esperais, ó fina-flor da terra da Hélade,/ para matar, massacrar os bárbaros e do alto do navio/ atirá-los ao mar?" (v. 1593-5). Helena os incita: "Onde a vossa glória troiana?/ Mostrai-a a estes homens bárbaros" (v. 1603-4). Dessa vez, ela está definitivamente ao lado dos gregos contra os inimigos, e nem Helena nem Menelau parecem fazer referência à guerra de Troia de forma ambígua. Ao contrário, a glória de Troia é lembrada de forma orgulhosa, em clara referência ao código heroico (Meltzer, 1994). Menelau diz: "Não desonrarei a glória adquirida em Troia" (v. 845).

É certo que a ideia de um sacrifício que permita o retorno não é uma inovação euripideana. Na Odisseia, o preço que os feácios pagam por transportarem Odisseu é a petrificação da nau que o leva a Ítaca. Em Heródoto, Menelau, para deixar o Egito, sacrifica duas crianças de lá a fim de fazer os ventos soprarem a seu favor (Heródoto, II, 119). Mas a batalha final em Eurípides transforma o sacrifício em barbárie, atualizando o passado glorioso.

A relação com a guerra e com o retorno não é a mesma para todos na peça. Se para Helena e Menelau é preciso recuperar a glória na guerra, testando sua capacidade de ser atualizada, tendo em vista a guerra que a precede, o Coro, as personagens e a peça enquanto conjunto parecem repetir para Helena a pergunta que ela própria faz à tropa: "onde está a

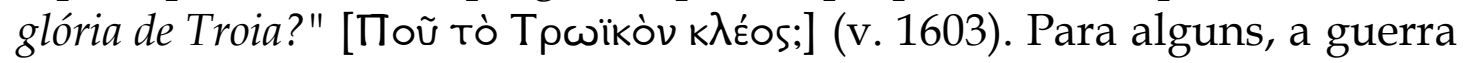
fora inútil, deplorável, de modo que mesmo a glória de seus maiores guerreiros havia se transformado em glória também inútil e deplorável. Teucro, sem nem mesmo saber da história do eídōlon de Helena, é um desses. A guerra, pelo resgate de Helena e pela honra de Menelau, 
resulta no suicídio do irmão e em seu próprio exílio de Salamina. Ao colaborar na destruição de Ílion, ele mesmo se perde (Helena, 106). Teucro fala se si como vítima e não como herói de guerra, ele condena a guerra recusando sua condição heroica (Helena, v. 72-7, 81, 162-3), sem poder distinguir entre os que foram vencedores e os que foram vencidos: "ao colaborar na sua destruição, eu próprio me perdi" (Helena, v. 106).

Eurípides estabelece um claro contraste entre o destino reservado aos heróis e aos guerreiros anônimos, uma vez que a Guerra de Troia, levada a cabo por um propósito vazio, um eídōlon, resulta na morte de milhares de gregos e troianos, "a tal ponto que nem vestígios seguros existem das muralhas" (Helena, v. 103) de Ílion, enquanto para Helena e Menelau os deuses preservam um final feliz, de retorno à pátria. Desde o prólogo, enfim, vê-se o terreno ser preparado para tornar evidente a discrepância entre o herói, que se revela um herói covarde no fim da

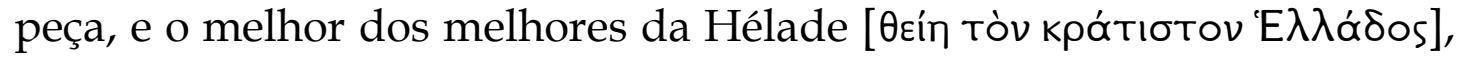
bem como entre esse herói e a massa, a grande multidão de mortais

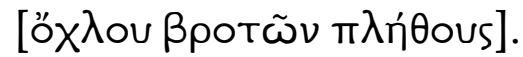

A guerra continua a ser vista como o caminho para a aquisição da glória heroica e como a solução para os males, a despeito dos versos do Coro: não é à toa que Helena, Menelau e seus companheiros poderão retornar à Hélade. Por outro lado, há uma completa condenação da Guerra de Troia, uma empreitada, no fim das contas, inútil e arrasadora; condenação indicada por Teucro, pelos guerreiros anônimos que vão à guerra sem transformarem-se em heróis, bem como pelo servomensageiro, que diz a Menelau: "inúmera fadigas sofreste em vão" (v. 603); ou ainda, que se pergunta depois de saber o que se passara: "Por uma simples nuvem tantos males suportamos?" (Helena, v. 706). Aí, aliás, no encontro do mensageiro com Menelau e, consequentemente, com Helena, trata-se, tal como argumenta Kannicht (1969), de uma das cenas de reconhecimento da peça. Ao reconhecer Helena, o mensageiro reconhece, por conseguinte, a futilidade da guerra e personifica, assim, toda a massa de guerreiros anônimos sobreviventes cujas vidas foram arruinadas pela guerra. A reação do mensageiro, tão diferente da reação de Menelau, ajuda a perceber o contraste entre o sofrimento do herói ignavo, que é recompensado, e o sofrimento da multidão, que, ao contrário, não recebe nenhuma paga:

Assim se farão as coisas, ó rei. Mas agora vejo como a arte dos adivinhos é falsa e cheia de mentiras.

[Nada há de verdadeiro na chama que arde, nem nas vozes dos seres alados. É ingenuidade 
pensar que as aves sirvam de ajuda aos mortais.]

Pois Calcas nada disse nem comunicou ao exército,

ele que, por uma nuvem, via morrerem os companheiros.

Também Heleno o não fez, e a cidade foi destruída em vão.

[Poder-se-á dizer que um deus assim o quis.

Que interessa então consultar os oráculos? Aos deuses convém

sacrificar, implorando os seus beneficios, e deixarmo-nos de profecias.

São pura invenção a servir de isca à existência

e ninguém, sem trabalhar, enriqueceu com as chamas dos sacrificios.

A razão e a prudência são a melhor profecia.]

(Helena, v. 744-57)

Também a batalha final põe em xeque a glória dos heróis e a dos inocentes, fazendo sobressair a primeira e apagando, como de costume, a segunda. A ferocidade da batalha vencida por Menelau contra seus inimigos desarmados se adequa perfeitamente a seu caráter de herói iliádico, da força bruta, bem como serve à ironia do poeta da qual é vítima: Menelau retoma sua glória troica massacrando remadores

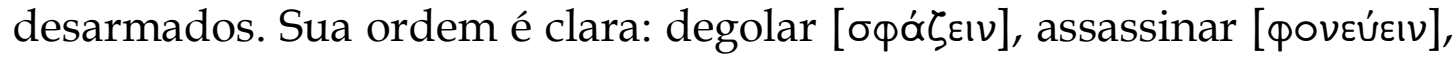

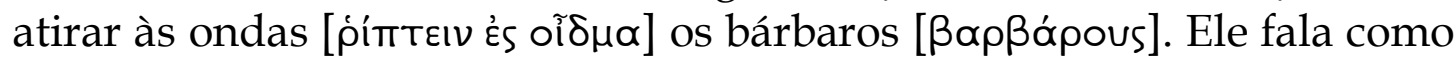
grande guerreiro, herói de grande fama; a ação, porém, nada tem de heroica. Menelau é covarde e a descrição detalhada do ato realça sua covardia.

"Que esperais, ó fina-flor da terra da Hélade, para matar, massacrar os bárbaros e do alto do navio atirá-los ao mar?" Aos teus marinheiros, por seu lado, o chefe dos remadores gritou ordem contrária:

"Eia, rápido! Não agarrarás um a ponta de um pau, pega outro num banco, retira outro ainda o remo do encaixe e sangue não fará jorrar da cabeça destes estrangeiros, nossos inimigos?"

Todos se ergueram e, de pé, pegaram com mãos ambas peças do navio, enquanto eles possuíam espada.

Do barco manava sangue. E ouvia-se a exortação de Helena, postada à popa: "Onde a vossa glória troiana? Mostrai-a a estes homens bárbaros." Na fúria do combate, uns tombam por terra e levantam-se, veem-se outros que jazem mortos. Menelau, de armas postas, observava os locais onde os companheiros fraquejam e a esse ponto acorria, de espada na mão direita, de tal modo que nos obrigou a deixar a nau e esvaziou os bancos de teus nautas. Dirigindo-se então ao homem do leme, ordenou-lhe que apontasse a proa à Hélade.

(Helena, v. 1597-613) 
A cena é, nas palavras de Verral, intolerável: "seria repulsiva se não fosse tão ridícula" (Verral, 1905: 54). ${ }^{10}$ Como achar ridícula, contudo, uma cena que empreende a guerra como solução para o retorno, quando o Coro já havia avisado: "Insensatos de vós, quantos na guerra buscais/glória, e nas lanças robustas, [...] o remédio para os males dos mortais". A peça não estaria colocando em cena a insistência na guerra como caminho para a solução? Não haveria ali não uma condenação da guerra em si, mas, mais do que isso, uma sugestão de que guerreiros, como Menelau, e, no limite, os anônimos, não saberiam definir seu destino senão por meio da guerra?

Para Karl Reinhardt (1972), Eurípides apresenta uma evidente crise de sentido do mundo antigo. Sua obra é o lugar da dúvida, da perda de sentido, da ausência de resposta. Essa crise de sentido que caracteriza as peças euripideanas é, por sua vez, um termômetro da mesma crise de sentido que marca o fim do século $\mathrm{V}$ a. C. em Atenas. Eurípides leva à cena não apenas batalhas como manobras da ilusão, paradoxos da psiquê. A alma humana aparece em sua ambiguidade, em sua fraqueza, em movimento e assustada, porque ela está justamente expatriada do universo dos deuses, universo que até então a submetia.

O mundo do qual trata Eurípides, onde reina a vingança e o castigo, não é o mundo da justiça e dos processos, é o mundo da guerra e da crueldade, cujas certezas morais estão abaladas em função da guerra em parte, um mundo real na Atenas de 412 a. C., em parte apenas um eídōlon (Saïd, 1978). Com os quase vinte anos de guerra contra Esparta e o recente desastre da Sicília, quando as pessoas estão se interrogando sobre a guerra, é ao mito de Helena, o motivo por excelência da guerra, que Eurípides recorre para propor sua reflexão. Com efeito, seu recurso não é inédito. Em torno de 420 a. C., Górgias, em seu Elogio de Helena, investiga a figura de Helena para explorar os limites do discurso e,

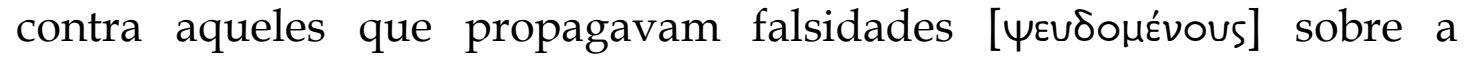
Tindárida, o sofista faz sua defesa. Cerca de 20 anos depois, Isócrates, a propósito do que escreve Górgias, afirma: "podemos julgar que ela é a causa [Eגévnv aitíav eĩval] de nós não termos nos tornado escravos dos bárbaros" (Isócrates, 67) ${ }^{11}$.

A linguagem, o enredo e a forma mesma de Helena de Eurípides expressam a tensão existente entre algo que é e algo que parece ser. Todas as personagens sofrem de alguma inapreensão da verdade (todos

\footnotetext{
10 Texto original: [it] would be repulsive if it were not too silly.

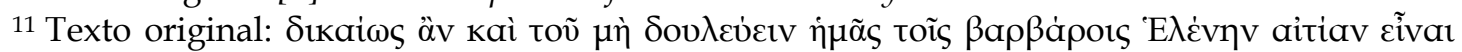

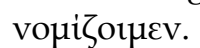


com exceção de Teónoe, que possui um entendimento e uma visão especiais). O Coro expressa sua ideia de verdade e falsidade, bem como Menelau e seu servo. Helena, mais que todos, sabe manipular as palavras, aproveitar-se da aparência. Ela ensina Menelau a mentir (Helena, v. 1049-84), sendo, de fato, sua habilidade com a imitação e a falsificação apresentada desde muito cedo na tradição, uma vez que, na Odisseia, como já citado, a Tindárida imita as vozes das esposas dos guerreiros aqueus a ponto de confundi-los (Od., IV, 277). Helena é uma peça, enfim, sobre o fingimento, a falsidade, a mentira, o erro, o engano, que guardam, não obstante, intenções e poder.

\section{Considerações finais: o Egito como nova Esquéria?}

Desde os escritores antigos, a ilha odisseica em que habitam os feácios é eleita pela tradição como o lugar, por excelência, para a discussão da verdade e da falsidade, havendo entre eles aqueles que enxergam na errância do herói um relato puramente fantástico e, por isso, mentiroso (Goldhill, 1991). É lá que as histórias vividas por Odisseu são contadas em primeira pessoa12. É apenas na Esquéria, portanto, que se pode escutar as histórias de dez anos de errância contadas por Odisseu, ele mesmo. Além disso, essas histórias permanecem na Odisseia de alguma forma preservadas na Esquéria, já que o caminho da ilha a Ítaca permanecerá desconhecido para os mortais. Afinal, Odisseu, o único que poderia revelá-lo, assim que sobe à côncava nau, "é tomado por um sono do qual não se acorda, dulcíssimo, semelhante à morte" (Od., XIII, v. 80) e todo o percurso de volta Odisseu perfaz adormecido.

Na Odisseia, a ida de Odisseu à terra dos feácios pode ser pensada em termos de uma viagem que leva a personagem a locais inacessíveis, onde impera uma verdadeira suspensão temporal (Brandão, 2010). A Esquéria é um mundo de transição entre a selvageria das viagens de Odisseu e o mundo humano ao qual ele quer regressar, Ítaca (Goldhill, 1991). Após Troia, confiando no que a Odisseia diz, a Esquéria é a única cidade de homens que Odisseu vê, até que retorne à sua cidade. E é lá que Odisseu, imprimindo uma significativa mudança narratológica, narrará o que viveu de Troia a Ogígia, de onde partiria com destino ao reino de Alcínoo. É lá, enfim, que Odisseu, "transforma sua experiência em narrativa e, consequentemente, também em conhecimento" (Brandão, 2010: 18). Dessa narrativa, Odisseu faz por se confirmar herói, passando pelo

\footnotetext{
12 Por mais que aludidas novamente, após uma noite de amor com Penélope, as histórias contadas por Odisseu aos feácios o são, neste segundo momento, narradas pelo poeta e não

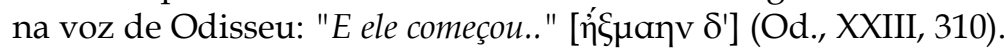


que passou e narrando o que se passou. Ao visitar a Esquéria e ser hospedado pelos feácios, Odisseu encontra um lugar em certa medida (medida da qual não se tem certeza até o momento de sua chegada, mas da qual se passa a ter após sua saída) ocultado à experiência humana. Com o castigo de Posêidon aos feácios, a nau petrificada, Odisseu torna-se, se não o único, pelo menos o último dos homens que poderia tanto ter visitado a remota terra dos feácios quanto ter sido transportado por eles, os amigos dos remos. Também as naus feácias sugerem sua ucronia, no sentido literal de não-tempo, agudizando a incerteza quanto à localização e à existência da Esquéria. A velocidade com que elas cruzam o abismo dos mares aponta para uma temporalidade inacessível aos homens mortais. E o sono que acomete Odisseu quando de sua ida a Ítaca só pode reforçar, no receptor da narrativa, a ideia de que a Esquéria seria, ou pouco localizável - no tempo e no espaço -, ou tão escondida nos confins da terra que seria inacessível e, assim, preservada na memória de Odisseu como lembrança, mas não como um lugar a se voltar.

Em Helena de 412 a. C., Eurípides parece ter escolhido o Egito como uma espécie de remapeamento da Esquéria, pois é lá também que o retorno do herói da peça, Menelau, e de sua esposa se define, bem como é lá que tudo o que havia sido feito por ele ao longo dos últimos anos, desde o início da expedição dos aqueus para Troia, é posto em xeque. Sobretudo, é lá que, tal como Odisseu fizera ao narrar seus feitos para os feácios, reconhecendo-os, Menelau vai também reconhecer os seus, mas, ao contrário do Laertíade, que confirma ser o herói multiastucioso, Menelau faz da covardia sua vocação guerreira. Como ocorre com a Esquéria na Odisseia, o Egito em Helena, apresentando-se como limiar entre dois mundos, o da verdade e o da falsidade ou o da verdade e da mentira, aposta na fluidez entre esses dois valores, a verdade e a falsidade ou a verdade e a mentira, para atualizar o mito.

Escolhendo a versão de Estesícoro, aludida por Platão, Eurípides se apropria de uma visão do Egito já existente na tradição para elaborar as inquietações de sua peça e de seu mundo. A estratégia poética de Eurípides parece ter sido, assim, recorrer à falsidade, ao falso, ao negativo do mito, que é mito também, para justamente indagar a realidade naquilo em que ela não havia sido indagada por meio das narrativas mais comuns sobre Helena. Eurípides, para falar da guerra (e Atenas estava em guerra!), do que a guerra faz, do sofrimento real que a guerra traz aos homens, dos seus homens e não dos seus heróis, vai precisar recorrer não à guerra, mas à mentira da guerra, à sua falsidade. $\mathrm{Na}$ peça, vê-se, por isso, o falso como valor, como um construto 
transformado em caminho narrativo, tal como sintetiza o poeta: "muito

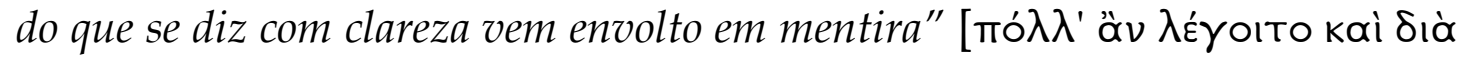

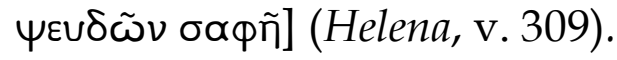

\section{Fontes antigas}

DIODORE DE SICILE. Bibliothèque Historique. Texte établi par Pierre Bertrac et traduit par Yvonne Vernière. Paris: Les Belles Lettres, 1993.

EURIPIDE. Hélène. Texte établi et traduit par Henri Grégoire. Introduction et notes par Françoise Frazier. Paris: Les Belles Lettres, 2007.

EURIPIDES. Iphigeneia at Aulis, Rhesus, Hecuba, The Daughters of Troy, Helen. With an English translation by Arthur S. Way. London: William Heinemann. New York: G. P. Putnam's Sons, 1916.

EURIPIDES. Electra, Orestes, Iphigeneia in Taurida, Andromache, Cyclops. With an English translation by Arthur S. Way. London: William Heinemann. New York: The Macmillan Co, 1912.

EURÍPIDES. As Troianas. Introdução tradução do grego e notas de Maria Helena da Rocha Pereira. Lisboa: Edições 70, 2014.

EURÍPIDES. Duas tragédias gregas: Hécuba e Troianas. Tradução e introdução Christian Werner. São Paulo : Martins Fontes, 2004.

EURÍPIDES. Electra. Trupersa. Trupe de tradução de teatro antigo. Direção de tradução de Tereza Virgínia Ribeiro Barbosa. Cotia: Ateliê Editorial, 2015.

EURÍPIDES. Helena. Versão do grego, introdução e notas José Ribeiro Ferreira. Porto Alegre: Movimento, Instituto de Estudos Clássicos da Faculdade de Letras da Universidade de Coimbra, 2009.

EURÍPIDES. Orestes. Introdução, tradução e notas de Augusta Fernanda de Oliveira e Silva. Textos Clássicos - 13. Coimbra: C.E.C.H, 1982.

Euripidis fabulae, vol. 2, Ed. J. Diggle. Oxford: Clarendon Press, 1981; 1994.

Euripidis fabulae, vol. 3, Ed. J. Diggle. Oxford: Clarendon Press, 1994.

GORGIA. Encomio di Elena. Testo critico, introduzione, traduzione e note a cura di Francesco Donadi. Roma: L'Erma di Bretschneider, 1982. 
HÉRODOTE. Histoires, 9 vols, Ed. Legrand, Ph.-E. Paris: Les Belles Lettres, 1932; 1968.

HERÓDOTO. História. Tradução do grego, Introdução e Nots de Mário da Gama Kury. Editora Universidade de Brasília, 1985.

HESIOD. Theogony. Ed. West, M.L. Oxford: Clarendon Press, 1966.

HESÍODO. Teogonia: a origem dos deuses. Estudo e tradução de Jaa Torrano. São Paulo: Iluminuras, 2007.

HOMER. Odyssey - I. With an English translation by A. T. Murray.

Cambridge: Harvard University Press. London: William Heinemann Ltda, 1955.

HOMER. Odyssey - II. With an English translation by A. T. Murray. London: William Heinemann Ltda. New York: G. P. Putnam's Sons, 1919.

Homeri Ilias, vols. 2-3, Ed. Allen, T.W. Oxford: Clarendon Press, 1931.scepe:

Homeri Odyssea, Ed. Peter von der Mühll, P. Basel: Helbing \& Lichtenhahn, 1962.

HOMERO. Ilíada. Tradução de Frederico Lourenço.São Paulo: Penguin Classics; Companhia das Letras, 2013.

HOMERO. Odisseia. Tradução de Frederico Lourenço. São Paulo: Penguin Classics; Companhia das Letras, 2011.

ISOCRATE. Discours. Tome I. Texte établi et traduit par Georges Mathieu et Émile Brémond. Paris: Les Belles Lettres, 1972.

ISOCRATES. Orations - III. With an English translation by Larue Van Hook. Cambridge: Harvard University Press. London: William Heinemann Ltda, 1945.

Lycophronis Alexandra, vol. 2, Ed. Scheer, E. Berlin: Weidmann, 1958.

PLATÃO. Fedro. Texto grego John Burnet; tradução Carlos Alberto Nunes. 3. ed. Belém: ed. ufpa, 2011.

PLATO. Euthyphro, Apology, Crito, Phaedo, Phaedrus. With an English translation by H. N. Flower and an introduction by W. R. M. Lamb. London: William Heinemann. New York: The Macmillan Co, 1913.

PLATON. Fédre. Tome IV - 3e Partie. Texte établi par Claudio 
Moreschini et traduit par Paul Vicaire. Paris: Les Belles Lettres, 1994.

Platonis opera, vol. 2, Ed. Burnet, J. Oxford: Clarendon Press, 1901, Repr. 1967.

PROCLUS. Chrestomathia. Recherches sur la Chrestomathie de Proclus, vol. 4, Ed. Severyns, A. Paris: Les Belles Lettres, 1963.

PROCLUS. Greek epic fragments: from the seventh to the fifth centuries BC. Martin L. West (edition and translation). Cambridge, Mass.; London: Harvard University Press, 2003.

STESICHORUS. The poems. Edit. and transl. M. Davies and P. J. Finglass. Cambridge University Press, 2015.

\section{Referências bibliográfias}

BEECROFT, Alexander. This is not a true story: Stesichorus's Palinode and the Revenge of the Epichoric. Transactions of the American Philological Association, Volume 136, Number 1, Spring 2006, p. 47-70.

BRANDÃO, Jacyntho Lins. A experiência de Ulisses: nota sobre um tema utópico perdido. Revista Morus - Utopia e Renascimento 7. Dossiê "Utopia e viagem. Tão longe, tão perto". 2010, p. 15-26.

COELHO, Maria Cecília. Eurípides, Helena e a Demarcação entre Retórica e Filosofia. 2002. Tese (Doutorado em Letras Clássicas). Universidade de São Paulo, USP, Brasil. 2002.

GOLDHILL, Simon. The poet's voice: Essays on poetics and Greek literature. Cambridge: Cambridge Univ. Press, 1991.

GOOSSENS, Roger. L'Égypte dans l'Hélène d'Euripide. Égypte Pharaonique. Chronique 20, juillet 1935, p. 243-53.

KANNICHT, R. Euripides, Helena. Heidelberg: Winter, 1969.

MELTZER, Gary S. Where Is the Glory of Troy? Kleos in Euripides' "Helen". Classical Antiquity, Vol. 13, No. 2 (Oct., 1994), p. 234-55.

MOERBECK, Guilherme Gomes. O pensamento de Eurípedes e a política durante a Guerra do Peloponeso. 2013. 242 f. Tese (Doutorado em História). Instituto de Ciências Humanas e Filosofia, Universidade Federal Fluminense, Rio de Janeiro. 2013. 
REECE, Steve. The Stranger's Welcome: Oral Theory and the Aesthetics of the Homeric Hospitality Scene. Michigan Monographs in Classical Antiquity. Ann Arbor: University of Michigan, 1993.

REINHARDT, Karl. La crise du sens chez Euripide (1958). In: REINHARDT, Karl. Eschyle; Euripide. Trad. par Emmanuel Martineau. Paris, Gallimard, 1972.

ROSE, Gilbert. "The Unfriendly Phaeacians". Transactions and Proceedings of the American Philological Association. Vol. 100, (1969), p. 387-406.

SAÏD, Suzanne. Euripide ou la critique de la responsabilité mythique. In: SAÏD, Suzanne. La faute tragique. Paris: Librairie François Maspero, 1978.

SEGAL, Charles. Singers, Heroes, and Gods in the Odyssey. Ithaca; London: Cornell University Press, 1994.

VAN WEES, H. From kings to demigods: epic heroes and social change c. 750-600 BC. In: DEGER-JALKTZY, S.; LEMOS, I. S. (Org.) Ancient Greece: from the Mycenaean palaces to the age of Homer. Edinburgh: Edinburgh University Press, 2006, p. 363-79.

VIDAL-NAQUET, Pierre. Valeurs religieuses et mythiques de la terre et du sacrifice dans l'Odyssée. Annales: Économies, Sociétés, Civilisations. 1970. Vol. 25, p. 1278-1297.

VILLATE, Sylvie. L'insularité dans la pensée grecque. (PDF. Introduction.) Presses Univ. Franche-Comté. 1991.

WOODBURY, Leonard. Helen and the Palinode. Phoenix, Vol. 21, No. 3 (Autumn, 1967), p. 157-76. 